\title{
Xylitol, polyol molasses and glucose in the diet of newborn calves II. Content of antimicrobial factors in blood and saliva, bacteria in faeces and health status
}

\author{
HANNU KORHONEN ${ }^{1}$, EIJA ALASAARI and MATTI ANTILA \\ Department of Dairy Science, University of Helsinki, \\ SF-00710 HELSINKI 71, Finland \\ MIKKO TUORI and ESKO POUTIAINEN \\ Department of Animal Husbandry, University of Helsinki, \\ SF-00710 HELSINKI 71, Finland
}

\begin{abstract}
The concentrations of various antimicrobial factors in the saliva and plasma of newborn calves with special reference to possible effects of a diet supplemented with different sugar alcohols were studied. Eighteen calves were assigned alternately at birth to three groups, each comprising six animals. All calves were fed a pooled colostrum diet for the first four days, thereafter whole milk plus milk replacer. Concentrates and hay were given ad libitum. The diets of the different groups were supplemented with the following test substrates: xylitol, polyol molasses or glucose (control). The daily doses of each substrate were progressively increased from 0.5 to $1.0 \mathrm{~g} / \mathrm{kg}$ of live weight for the last four weeks. Plasma and saliva samples were taken from all calves before colostrum feeding (day 0 ) and on days $1,2,4,7,21$ and 35 after birth. The following factors were determined quantitatively: lactoferrin (LF), lactoperoxidase (LP), lysozyme (LZM) and immunoglobulins $\operatorname{IgG}_{1}, \operatorname{IgG}_{2}, \operatorname{IgM}$ and $\operatorname{IgA}$ (only in plasma).

Further determinations included weekly counts of total aerobic bacteria, aerobic haemolytic bacteria, coliforms, lactobacilli and clostridia in faeces.

Salivary LF increased from the average 0 day level of $3.6-17.0 \mu \mathrm{g} / \mathrm{ml}$ in the different groups to a maximum of $38.7-55.6 \mu \mathrm{g} / \mathrm{ml}$ within one week, and declining thereafter slowly in all groups. LF was not found in the saliva of all calves at birth, but was consistently present later on. No LF was detected in plasma. Salivary LP increased from the average 0 day level of $56.3-86.6 \mu \mathrm{g} / \mathrm{ml}$ in the different groups to a maximum of $228-296 \mu \mathrm{g} / \mathrm{ml}$ within three weeks and declined markedly by day 35 . LP was found in all saliva samples, but the plasma concentrations were very low and not always detectable. Salivary LZM was high at birth compared to the plasma level (average $0.8-2.1 \mu \mathrm{g} / \mathrm{ml}$ vs. $0.3-0.5 \mu \mathrm{g} / \mathrm{ml}$ in the different groups)
\end{abstract}

\footnotetext{
I Present address: Ministry of Livestock Development, P.O. Box 68228, Hill Plaza, Nairobi, Kenya.
}

Index words: antimicrobial factors, lactoperoxidase, lactoferrin, lysozyme, calves, blood, saliva, xylitol, polyols, faecal bacteria 
but dropped within one week in all groups, reaching the plasma level by day 21 . No clear changes were observed in the LZM plasma concentration. Except for $\mathrm{IgG}_{2}$, there was a rapid but transient increase in the plasma levels of all $\mathrm{Ig}$ 's, in particular of $\mathrm{IgG}_{1}$, after the first colostrum feeding. From day 7 the levels of Ig's with the exception of $\operatorname{IgG}_{2}$, started to rise again. There were no statistically significant differences in any of the investigated antimicrobial factors or bacterial groups between the feeding groups, except for clostridia which exhibited the highest count $(\mathrm{P}<0.05)$ in the xylitol group. Also the average salivary LF, LZM and IgG, levels were highest, and the health status was best in the xylitol group. The results suggest that, besides antibodies, LF, LZM and LP, which are present in maternal colostrum and also in saliva of the newborn calf, may contribute considerably to the protection of the calf against pathogens during the first weeks of life.

\section{Introduction}

The importance of colostrum feeding for the survival and health of the newborn calf is well established (for recent literature, see Porter et al. 1977, Ann. Rech.Vet. 9 (2) 1978 and Roy 1980). The protection provided by the colostrum is primarily attributable to antibodies which are absorbed from the calf's intestine into circulation during the first 24-36 hours after birth, the absorption time depending on the class of immunoglobulin (Penhale et al. 1973, Logan et al. 1978, Stott and Menefee 1978, Stott et al. 1979 a, 1979 b, Bush and Staley 1980). In addition to systemic immunity, colostral antibodies seem to confer local protection against microbial infections within the gastrointestinal tract (LoGAN et al. 1974 b).

Besides antibodies, the colostrum and postcolostral milk contain varying amounts of non-specific antimicrobial factors such as lactoferrin (LF), lysozyme (LZM) and the lactoperoxidase (LP) system as well as living cells (for recent reviews, see REITER 1978 a, 1978 b, KORHONEN et al. 1978). Their potential role in the protection of neonatal calves against enteric or systemic infections is as yet little explored, but their concentrations in colostrum have been the subject of recent studies (Korhonen 1977, MERILÄINEN et al. 1979). Recently, ReITER et al. (1980) showed that the LP system can be activated in vivo in the abomasum of the calf, and this may contribute to its resistance to infections. It appeared, therefore, worth investigating the occurrence of the above antimicrobial factors in the saliva and blood of newborn calves and the effect of colostrum feeding on their concentrations. The present study was carried out as part of a trial on the effects of supplementing the colostrum-based diet with different sugar alcohols.

Therefore their potential influence was evaluated, with special reference to studies of MÄKINEN et al. (1975) according to which long-term xylitol diet enhanced the peroxidase activity in human saliva and reduced the frequency of caries. In the first part of the present study, the results of certain physiological parameters and growth of the calves are described (TUORI 1984).

\section{Materials and methods}

\section{Arrangement of the feeding trial}

The details of the experimental procedures have been described in the first part of the present paper (TUORI 1984). In brief, the feeding was arranged as follows: 18 newborn, unsuckled calves were assigned randomly, within sex, to three groups, each comprising six animals. Each group was fed during the first week a basic colostrum- and whole milk based diet, then a commercial milk replacer diet, supplemented with one of the following test substrates: polyol molasses, xylitol and glucose (control group). The feeding scheme was as follows: 


\begin{tabular}{ccccc}
\hline $\begin{array}{l}\text { Day after } \\
\text { birth }\end{array}$ & $\begin{array}{c}\text { Colostrum } \\
\text { \% of live } \\
\text { weight }\end{array}$ & $\begin{array}{c}\text { Whole milk } \\
\text { \% of live } \\
\text { weight }\end{array}$ & $\begin{array}{c}\text { Test substrate } \\
\text { g/kg of live } \\
\text { weight }\end{array}$ & $\begin{array}{c}\text { Total amount } \\
\text { of liquid } \\
\text { diet } ~\end{array}$ \\
\hline 1
\end{tabular}

1 Liquid diet contained whole milk, milk replacer $(140 \mathrm{~g}$ powder in one litre water) $+1 \mathrm{~g}$ test substrate per $\mathrm{kg}$ live weight.

Concentrates and hay were given ad libitum. The composition of the polyol molasses has been given in the first part of the present paper (TUori 1984). All test substrates were mixed in a liquid form with colostrum or milk immediately before feeding. The calves were fed individually twice a day. The first feeding took place about $2-6$ hours after birth.

\section{Colostrum and milk for feeding}

Colostrum was pooled from the first six milkings post partum from several cows and stored frozen until feeding. Whole milk was collected from milk tank at a time and frozen. The concentrations of various antimicrobial factors were examined, and the result is given in the following table:
Sampling and analyses

Blood and saliva were collected from all calves according to the following schedule: 0 (before colostrum feeding), 1, 2, 4 and 7 days after birth and at three weeks ( 21 days) and five weeks (35 days) of age.

Blood samples were taken from the jugular vein into heparinized tubes. The red cells were separated by centrifugation, and plasma was stored at $-20^{\circ} \mathrm{C}$ until analyzed. The saliva samples were also stored at $-20^{\circ} \mathrm{C}$.

The concentrations of the different immunoglobulins ( $\operatorname{IgG}_{1}, \operatorname{IgG}_{2}, \operatorname{IgM}$ and $\left.\operatorname{Ig} A\right)$ were measured in plasma samples by the radial immunodiffusion gel technique according to FAHEY and McKelvey (1965). The specific antisera and lyophilized standard Ig's were purchased from Miles Laboratories (Indiana, USA).

\begin{tabular}{lccccccc}
\hline Sample & $\begin{array}{c}\text { Lysozyme } \\
\mu \mathrm{g} / \mathrm{ml}\end{array}$ & $\begin{array}{c}\text { Lacto- } \\
\text { peroxidase } \\
\mu \mathrm{g} / \mathrm{ml}\end{array}$ & Lactoferrin & & \multicolumn{3}{c}{ Immunoglobulins } \\
\cline { 5 - 8 } & 0.8 & 61.5 & $\mu \mathrm{g} / \mathrm{ml}$ & $\mathrm{IgG}_{1}$ & $\mathrm{IgG}_{2}$ & $\mathrm{IgM}$ & $\mathrm{IgA}$ \\
\hline Colostrum & 0.4 & 46.0 & 0.50 & 4.2 & 0 & 0.4 & 2.9 \\
Whole milk & 0.4 & 0.07 & 0.6 & 0 & 0.3 & 0.3 \\
\hline
\end{tabular}

The data on the compositional parameters analyzed from colostrum and milk have been presented in the first part of the present paper (TUORI 1984).
Both plasma and saliva samples were assayed for concentrations of lysozyme (PARRY et al. 1965), lactoferrin (AHONEN et al. 1978) and lactoperoxidase (KORHONEN et al. 1977). 
Rectal faeces samples were taken weekly from every calf and the following quantitations were made:

Total count of aerobic bacteria: $10 \%$ sheep blood agar (Blood Agar Base, Merck $\mathrm{Ag}$, Darmstadt), incubation for $2-3$ days at $+37^{\circ} \mathrm{C}$.

Haemolytic aerobic bacteria: as above, but only colonies with haemolytic zones around them were observed.

Coliform bacteria: Ergitol -7- Agar (Merck Ag, Darmstadt) aerobic incubation for 1 day at $+37^{\circ} \mathrm{C}$.

Lactobacilli: MRS Agar (Merck Ag, Darmstadt), anaerobic incubation in Gas
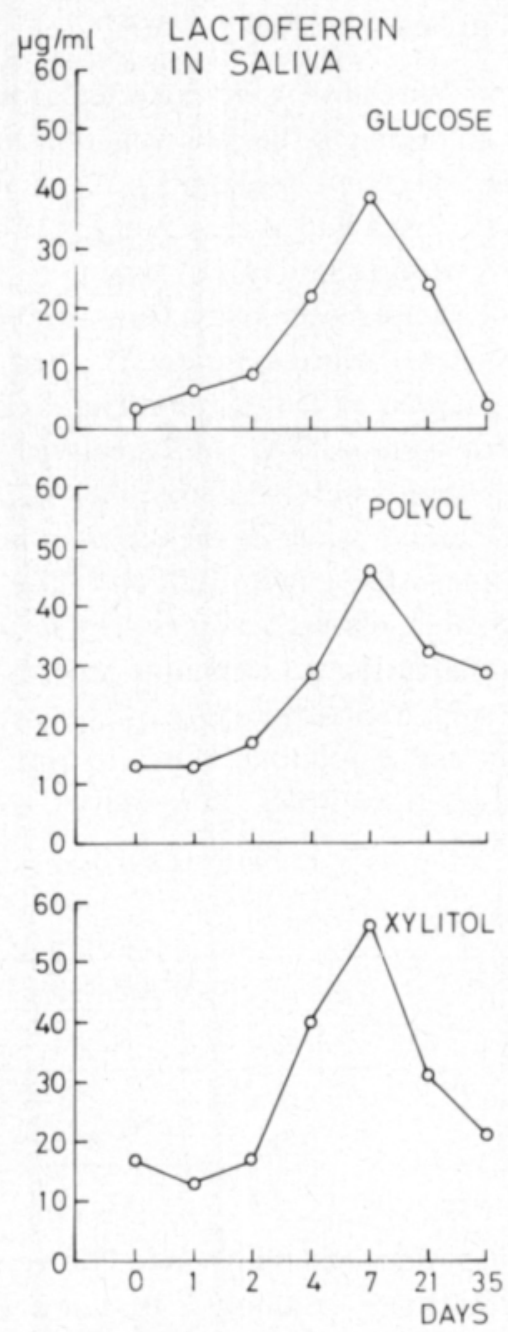

Fig. 1. Mean concentrations of lactoferrin in saliva of different feeding groups.

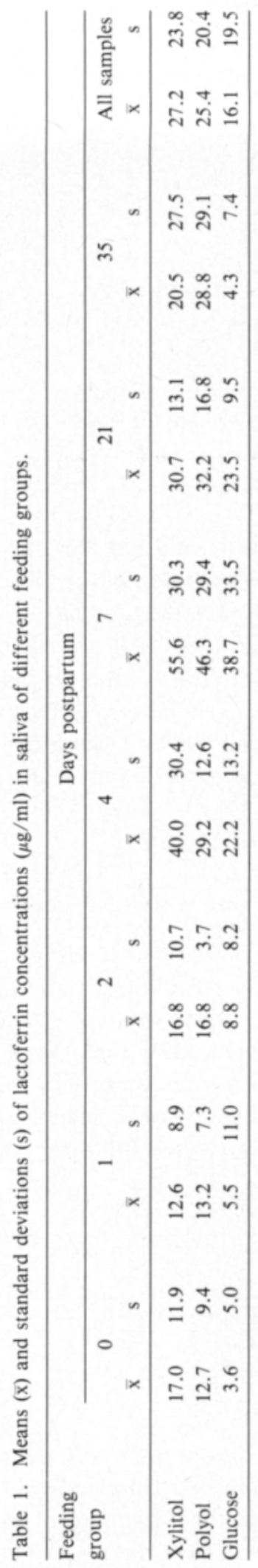


Pak chamber under $5 \% \mathrm{CO}_{2}$ for 3 days at $+37^{\circ} \mathrm{C}$.

Clostridia: RCM-broth (Merck Ag, Darmstadt), anaerobic incubation for 7 days at $+37^{\circ} \mathrm{C}$.

The health status of the calves was examined by daily recordings of possible incidence of diarrhoea and general physiological condition.

\section{Results}

\section{Lactoferrin (LF)}

LF was detected in no plasma samples. Neither was it found in the saliva of all calves at birth, but it was present later on. In each feeding group, the LF concentration peaked within seven days and declined almost to the birth level by day 35 (Fig. 1). There were great interindividual variations in LF in each group, as seen from the standard deviations in Table 1. Throughout the trial the average level of LF was lower in the glucose group than in the other groups, but statistically significant $(\mathrm{P}<0.05)$ differences could be confirmed only when the calves were 35 days old.

\section{Lactoperoxidase (LP)}

LP was present in all saliva samples, but the concentrations varied widely (range $1.0-690.0 \mu \mathrm{g} / \mathrm{ml}$ ), depending on the time of sampling and the calf (Table 2). In all groups, the LP saliva level rose clearly, though transiently, after the first colostrum feeding. It rose again from day 2 and peaked in all groups (3-4 times the birth level) on day 21 after which the level fell sharply almost to the birth level (Fig. 2). Throughout the trial the average LP concentration was noticeably lower in the glucose group compared to the other groups, but this difference was not statistically significant at any sampling time.

Compared to saliva, the LP plasma concentration was very low and was not always 
detectable in all calves (Table 2). Although the average LP plasma level parellelled quite well with that of saliva, no statistically significant correlation between these concentrations could be established.

\section{Lysozyme (LZM)}

At birth, LZM activity was present in the saliva and plasma of all calves. In subsequent
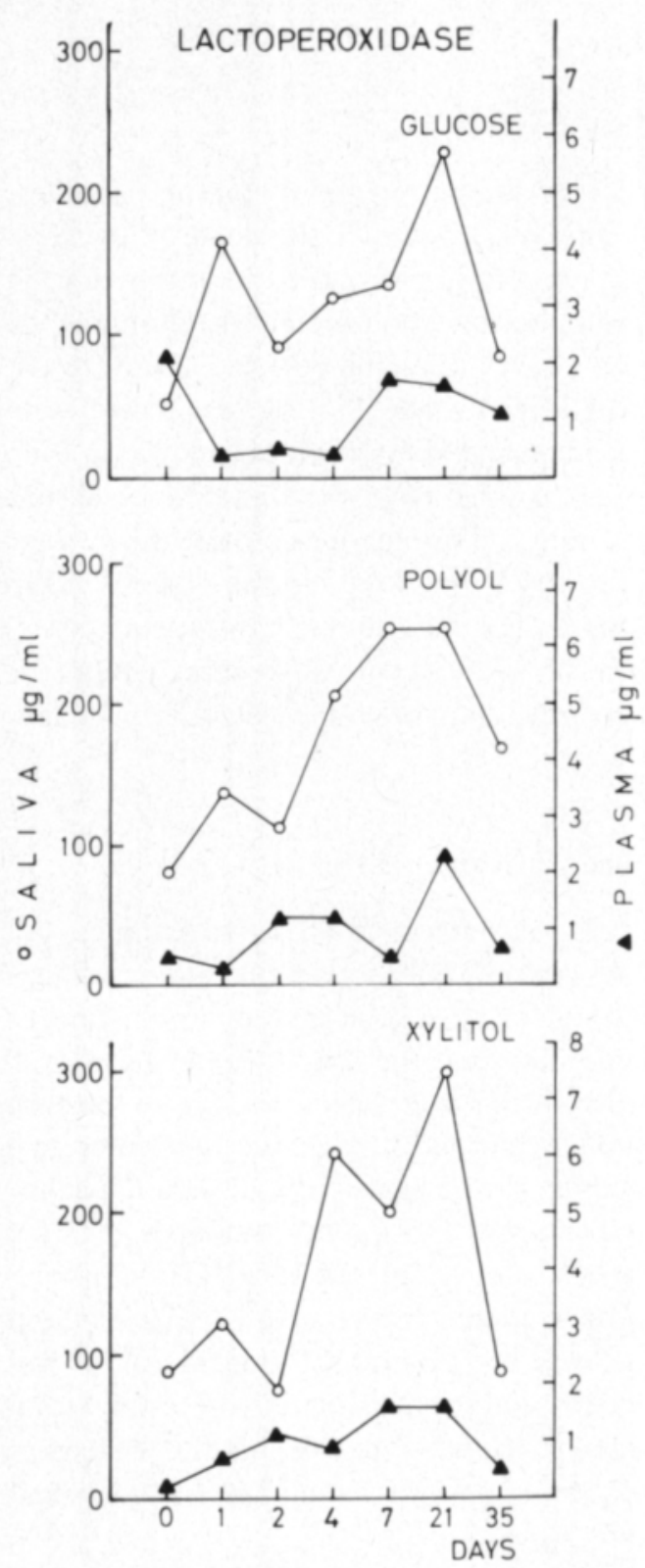

Fig. 2. Mean concentrations of lactoperoxidase in saliva and plasma of different feeding groups. samples it was, however, not always detectable. During the first week of life, the salivary LZM concentration was about twice the plasma concentration, but thereafter the salivary LP dropped to the plasma level in all groups (Fig. 3, Table 3). In contrast to the wide interindividual and time-related fluctuations observed in the salivary LZM, the LZM plasma level remained relatively constant throughout the trial. No statistically significant differences in the level of this enzyme were observed between the different groups. However, the average level tended to be lowest in the glucose group.
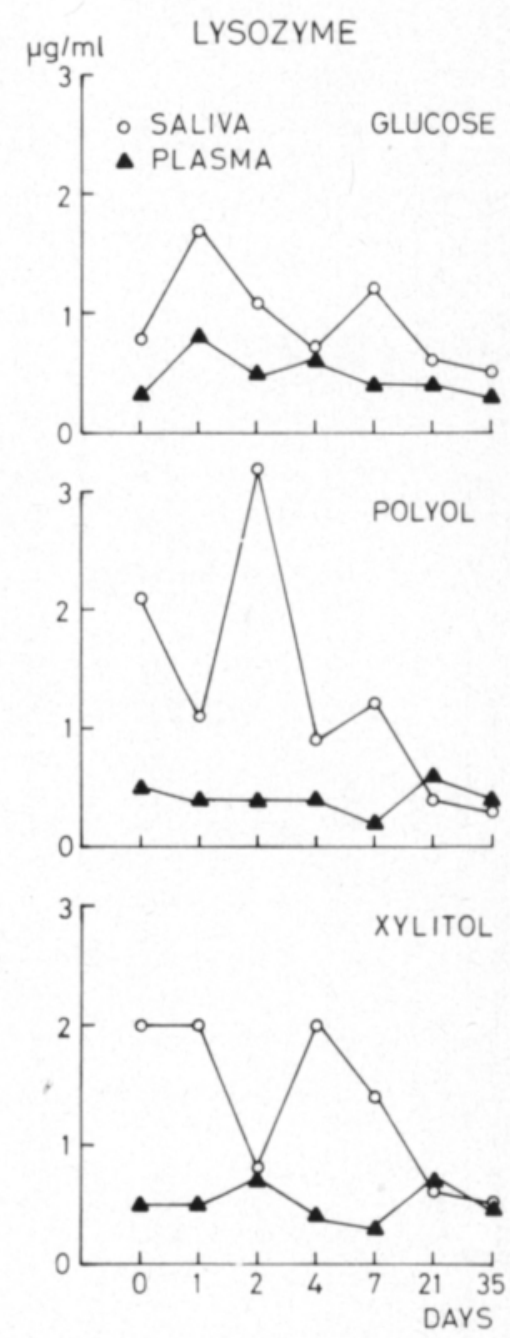

Fig. 3. Mean concentrations of lysozyme in saliva and plasma of different feeding groups. 


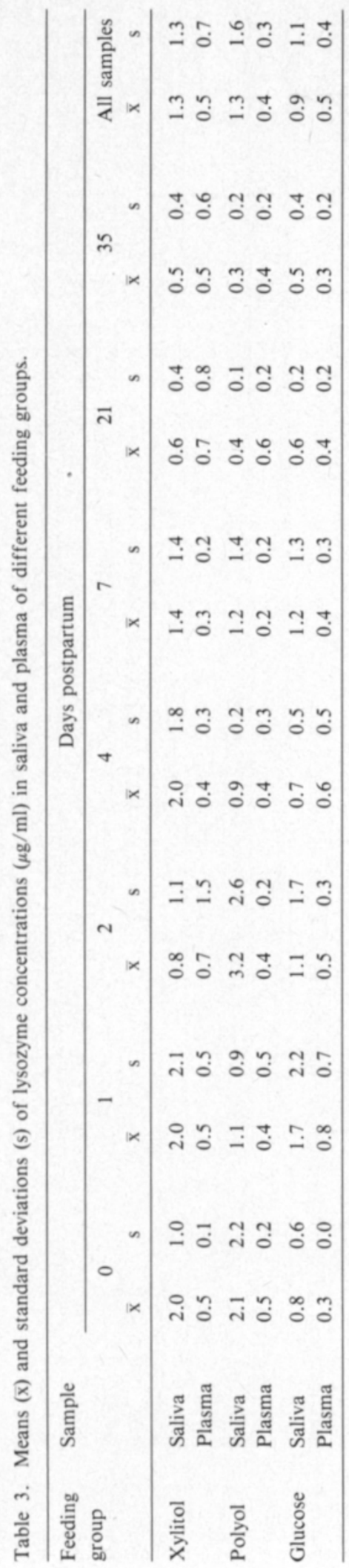

Immunoglobulins (Ig)

Before the first colostrum feeding, the concentrations in all Ig classes were low or undetectable in the plasma of all calves (Table 4). Following colostrum ingestion the levels of all Ig's increased rapidly and peaked within one or two days (Fig. 4). In particu-
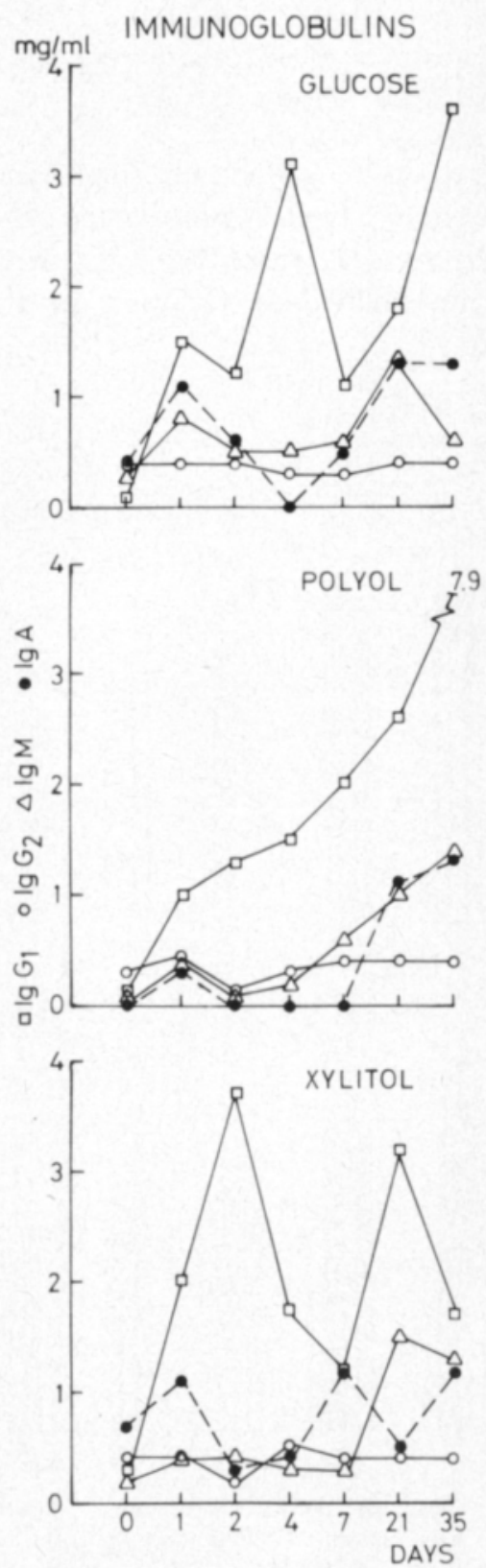

Fig. 4. Mean concentrations of various immunoglobulins in plasma of different feeding groups. 
lar, the $\mathrm{IgG}_{1}$ level increased by manyfold, but declined after a few days, remaining, however, above the birth level in most calves. In the polyol group, no such decline was observed.

The rise of $\mathrm{IgM}$ and $\mathrm{IgA}$ was relatively small and transient, whereas the $\mathrm{IgG}_{2}$ level remained almost unchanged. Towards the end of the trial period (at 21 and 35 days) the concentrations of all Ig's, except for $\mathrm{IgG}_{2}$, began to rise sharply.

There was no statistically significant difference in any Ig class between the different groups. As seen from Table 4, there was great interindividual variation in the $\mathrm{Ig}$ classes.
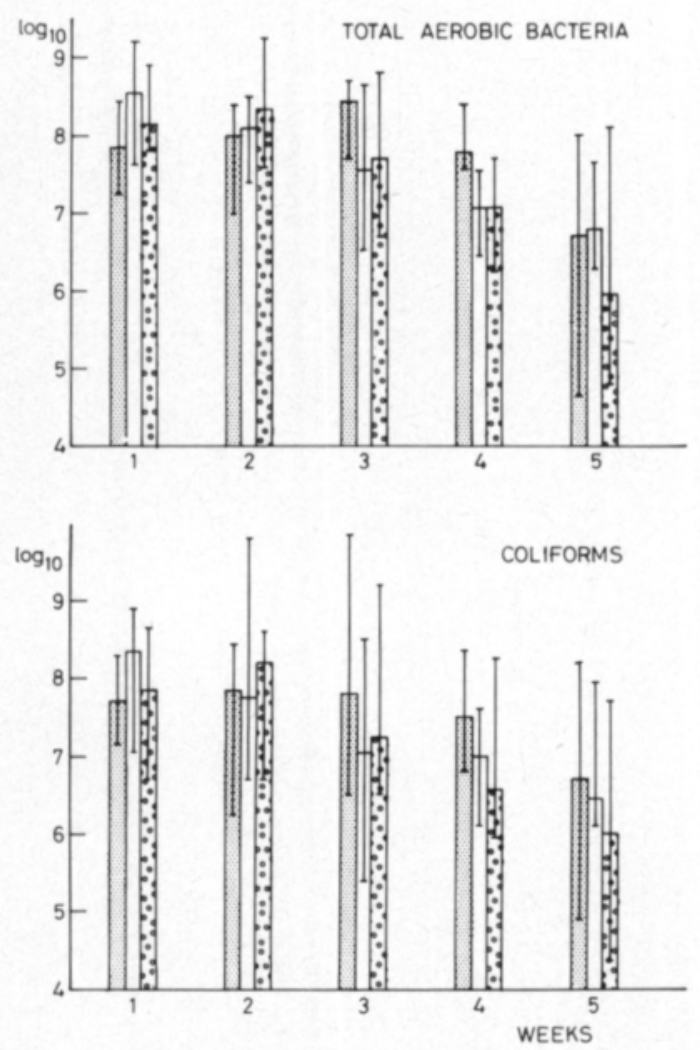

Fig. 5. Geometric means and ranges of variation of total aerobic bacteria and coliforms in the faeces of different feeding groups. xylitol group, $\square=$ polyol group, $[\bullet]=$ glucose group.

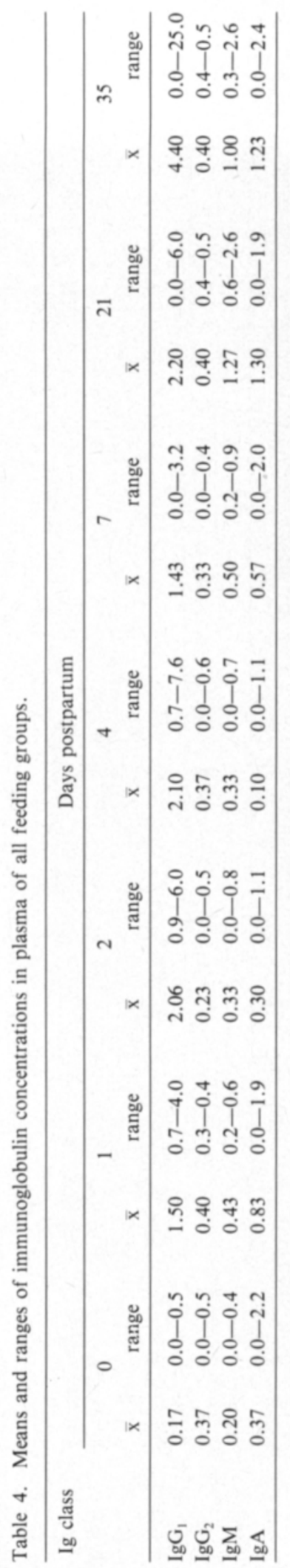




\section{Bacterial content}

Total aerobic bacteria

The total number of aerobic bacteria in faeces of individual calves varied between $10^{6}-10^{9} / \mathrm{g}$ during the first three weeks, the mean count for all feeding groups being $10^{8} / \mathrm{g}$ (Fig. 5). Thereafter, the counts decreased in all groups to an average of $10^{6} / \mathrm{g}$, but the interindividual range of variation remained large $\left(10^{4}-10^{8} / \mathrm{g}\right)$.

\section{Aerobic haemolytic bacteria}

These bacteria were found irregularly in faeces of all calves, and their occurrence in high numbers coincided with the diarrhoea. The average counts in positive samples of different groups varied between $10^{7}-10^{8} / \mathrm{g}$ during the first and second week, and decreasing thereafter to $10^{3}-10^{6} / \mathrm{g}$ by the fifth week. Also the frequency of positive findings diminished in all groups in the course of the trial. The total number of positive samples was lowest in the xylitol group ( 9 positive, $\mathrm{n}=30)$ and highest in the polyol group (17 positive, $\mathrm{n}=30$ ). In the glucose group, 12 out of 30 samples were positive.

\section{Coliforms}

The average number of coliform bacteria varied in different groups between $10^{6}$ and $10^{9} / \mathrm{g}$ (mean $10^{8} / \mathrm{g}$ ) during the first two weeks.

Thereafter, the counts of all groups decreased slowly to an average of $10^{6 / g}$, but the range of variation between different calves still remained large $\left(10^{4}-10^{8} / \mathrm{g}\right)$ (Fig. 5).

\section{Lactobacilli}

The number of lactobacilli increased slightly in every group during the first three weeks. Mean count $10^{9} / \mathrm{g}$, thus represented the predominant bacterial group. The count then decreased to an average level of $10^{8} / \mathrm{g}$ (Fig. 6).

\section{Clostridia}

The number of clostridia in faeces varied greatly between individual calves $\left(10^{2}-\right.$ $10^{7} / \mathrm{g}$ ), but an average level of $10^{4}-10^{5} / \mathrm{g}$ was maintained in all groups throughout the trial (Fig. 6). The counts were constantly higher in the xylitol group than in the other groups, the difference being significant at $\mathrm{P}<0.05$. In the case of other investigated bacterial groups, no significant differences were established between the feeding groups.

Relationships between antimicrobial factors and bacterial content

A correlation analysis was carried out in order to determine the possible relationships
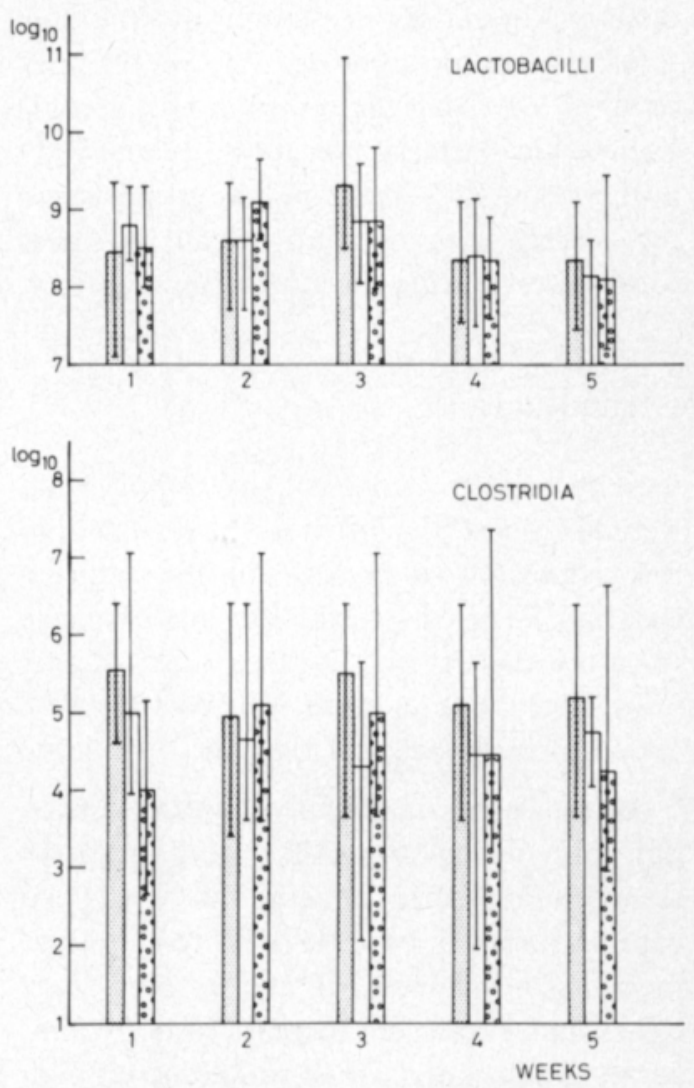

Fig. 6. Geometric means and ranges of variation of lactobacilli and clostridia in the faeces of different feeding groups. 圈 = xylitol group, $=$ polyol group, $\square=$ glucose group. 
between the concentrations of LF, LP and LZM in saliva and plasma and also between these factors and the content of different bacterial groups in faeces. These correlations were determined separately for each feeding group and for the total of all samples. The analysis indicated that with regard to all samples, salivary LF and LP correlated highly significantly $(\dot{r}=0.441, \mathrm{P}<0.001)$ with each other. The correlation was highly significant $(r=0.484, P<0.001)$ also in the polyol group and significant $(r=0.441$, $\mathrm{P}<0.01)$ in the xylitol group, whereas in the glucose group it showed no significance. No significant correlation was established between LZM and LF or LP, respectively. None of the above antimicrobial factors correlated significantly with any of the investigated bacterial groups. No statistical analysis was made on the relationships between the different $\mathrm{Ig}$ classes in plasma and the bacterial content of faeces. It is, however, interesting to note that the occurrence of aerobic haemolytic bacteria was most frequent (17 positive samples) in the polyol group where the average concentrations of all Ig classes were lowest during the first week of life.

\section{Health status}

In general, the calves of the xylitol group were healthiest. Only two of the six calves in this group showed any signs of illness during the trial. These calves exhibited mild scouring for a few days at two or three weeks of age, respectively, but no haemolytic bacteria were found in their faeces at the time of illness.

All the calves of the polyol group showed signs of scouring during the trial. Four calves showed diminished appetite on week two with haemolytic bacteria detected in their faeces. At one week of age, one of these calves had a transient increase in body temperature associated with a simultaneous high count of coliform in faeces. The remaining two calves had mild diarrhoea for a few days on the second and third week, respectively. It coincided with the appearance of haemolytic bacteria in the faeces.

In the glucose group, three calves exhibited mild diarrhoea on the second week. The other three calves showed dimished appetite during most of the time. An elevated temperature was recorded twice in one of these calves. During the duration of diarrhoea, haemolytic bacteria were found in faeces of all but one of the calves in this group. A selenium injection was administered intramuscularly to two and three calves of the glucose and polyol groups, respectively, during the first week. None of the calves in the xylitol group needed the injection.

\section{Discussion}

Recent studies have shown that bovine colostrum contains substantial quantities of non-specific antimicrobial factors. It appears therefore attractive to extend the immunological concept of colostrum for protection of the newborn to include also these nonantibody factors. However, in vivo evidence to support this is yet very limited and even the knowledge about the occurrence of antimicrobial factors, other than immunoglobulins, in the fluids of newborn and colostrumfed calves is scanty. The principal aim of the present study was, therefore, to obtain a picture of the levels of these factors in the saliva and plasma of newborn calves before and after colostrum feeding. For comparison the immunoglobulin concentrations were determined also in plasma, but no in saliva due to difficulties in obtaining quantitatively adequate samples.

In general, the results of this study reveal that there are enormous interindividual variations in the concentrations of all investigated antimicrobial factors in saliva and plasma, irrespective of the same age and sex and similar environmental condition. The reasons for this variability cannot be explained, but some influence of hereditary factors may be suggested.

With regard to the results on LF, LP and 
LZM concentrations no direct comparisons can be made with other studies due to lack of relevant data. It seems, however, justified to compare the present results with concentrations of the respective substances in colostrum and milk to obtain some indication of the importance of different antimicrobial factors to the calf.

The average level of salivary LF increased maximally by 3 - to 10 -fold within one week after birth. Nevertheless, even at its peak the LF concentration remained about ten times lower than that in colostrum and was also slightly lower than in the milk used for feeding. Since the LF level rose sharply during the time (day 4) the diet was converted from colostrum to whole milk, the observed increase is not attributable to colostral LF. Instead, it is probably due to a more pronounced synthesis of this protein in the buccal epithelium of the calf. Physiologically this is supported by the fact that the LF concentration of colostrum drops drastically within two days after parturition (KORHONEN 1977). Thus, the reduced intake of LF from colostrum is probably compensated by the commencement of the calf's own LF production. This seems to coincide with the time when the passive immunity provided by colostral antibodies is decreased (Fig. 4), and the calf's own Ig production has not yet reached the full capacity (LoGAN et al. 1974 b, Husband and Lascelles 1975). Therefore, at this particular period, the salivary LF could contribute to a greater extent to the defence mechanisms of the calf. LF remains active in the intestines, and the conditions there appear favourable for LF to become inhibitory (REITER $1978 \mathrm{a}, 1978 \mathrm{~b}$ ). It is of particular interest in this respect that no LF was found in the plasma of colostrumfed calves. This suggests that LF is not absorbed from the intestines into the circulation, even from the first colostrum feeding, though immunoglobulins having a higher molecular weight, are transferred unchanged in high amounts (Roy 1980). There are probably no such receptors for LF in the in- testinal epithelial surfaces, thus making it functional only within the gastrointestinal tract. Hence, further studies on the physiological significance of the colostral and salivary LF to the calf and the possible synthesis of this protein in the intestines would be warranted.

The level of salivary LP followed roughly the same pattern as that of salivary LF, with the exception of two peaks being observed for LP. At birth, the concentration was on the average at the same level as in the ingested colostrum but $3-4$ times the milk concentration. The small temporary increase on the first day may be attributable to colostrum intake, but the sharp increase found already on day 4 is probably due to the commencement of active LP synthesis in the salivary glands. Within three weeks, the concentration rose maximally by five - tenfold compared to that in colostrum and milk, declining thereafter to the original level by the end of the trial. The present results are contradictory to other studies (MORRISON and Steel 1968, Gothefors and Marklund 1975 and Reiter et al. 1980) in which the saliva of newborn calves was found to be poor in LP or devoid of it. Regarding the subsequent increase, our results are, however, in a line with the above studies.

The biological significance of LP is associated with its antimicrobial action in the presence of thiocyanate ions and hydrogen peroxide (REITER et al. 1964). This system has been previously shown to kill in vitro pathogens in human saliva (KLEBANOFF et al. 1966) and in bovine milk (REITER et al. 1976) and was recently found to be activated also in vivo in the abomasum of the calf (REITER et al. 1980). The results of the latter study suggest that salivary LP does not contribute to the bactericidal activity exerted by the LP system in the abomasal fluid. Thus, this activity is catalyzed principally by the LP contained in the ingested colostrum or milk. The above concept is supported by the fact that the colostral LP activity peaks within twothree days postpartum (KORHONEN 1977). 
The results of the present study, however, show that in addition to colostrum and milk, also saliva is an important source of LP in the newborn calf. However, it is not known whether the LP system is active in the calf's saliva, since it seems to contain only little $\mathrm{SCN}^{-}$(0.06 mM) (ReITER et al. 1980), and the source of $\mathrm{H}_{2} \mathrm{O}_{2}$ is uncertain. Therefore, further studies would be necessary to clarify this point. According to ReITER et al. (1980) the LP system is likely to be most active in the upper intestinal tract where there is enough $\mathrm{O}_{2}$ present to permit formation of $\mathrm{H}_{2} \mathrm{O}_{2}$. It may be provided either by a $\mathrm{H}_{2} \mathrm{O}_{2}$ generating system (e.g. glucose oxidase and glucose) with the diet or by $\mathrm{H}_{2} \mathrm{O}_{2}$ producing lactobacilli which occur naturally in large quantities in the abomasum of the calf. Sufficient $\mathrm{SCN}^{-}$is partly provided by colostrum and milk and partly by the active secretion in the abomasum. It appears, therefore, probable that this non-specific system has considerable significance in vivo in the prevention of enteric infections in preruminant calves. It would be interesting to investigate, whether the LP system is active in the case of feeding milk replacers instead of raw milk upon initial colostrum diet. In principle, the system should be active, since all its components are present, being provided by the calf itself.

The negligible peroxidase activities found in plasma throughout the trial suggest that the biological function of LP, like in the case of LF, is confined to the gastrointestinal tract.

At birth, the concentrations of salivary LZM were equal to or two-three times higher than the level found in the ingested colostrum. In spite of a large fluctuation, LZM remained on the average quite high during the first week, but dropped thereafter to the plasma level. The latter showed no clear changes throughout the trial and corresponded to the LZM level of the ingested milk. These results indicate that the calf is born with high levels of salivary LZM and suggest that the synthesis of this enzyme is impaired during the first week of life. The physiological behaviour of salivary LZM is thus contradictory to that of salivary LF and LP. Since the colostral LZM level is relatively low in the first milkings and reach the peak only 3-4 days postpartum (KORHONEN 1977), it appears logical to assume that this deficiency is compensated by high salivary LZM levels at birth. It remains, however, to be resolved whether the salivary or colostral LZM has any protective effect against enteric infections in the calf and whether the calf's intestines are capable of synthesizing this enzyme. It is interesting to note that in accordance with the results of LF and LP, the LZM plasma concentration was not affected substantially by colostrum or milk ingestion. This may be due either to the low LZM content which makes any change undetectable or to absorption being inhibited.

The plasma of most pre-colostral calves contained detectable amounts of immunoglobulins. The average concentrations observed for each class are in accordance with recent studies (McGuire et al. 1976, Baumwart et al. 1977, NAYLOR and KronFELDT 1977 and JENSEN 1978) and indicate that the bovine foetus is capable of synthesizing Ig. However, due to lack of antigenic stimulus, their quantities in body fluids are considered too low at birth to provide adequate immune protection against invading pathogens (Roy 1980). Colostrum ingestion resulted in a rapid but transient increase of plasma $\mathrm{IgG}_{1}$ being associated with a less pronounced rise of IgM and IgA levels. The average peak concentrations of all classes at 24 to 48 hours after birth are, however, 5 to 10 times lower than those found in previous studies (Porter 1972, Logan et al. 1974 b, McGuire et al. 1976, NAYLOR and KRONFELdT 1977, JENSEN 1978). This difference would rather be ascribed to a relatively low Ig content of ingested colostrum than to any inhibition of Ig absorption except for IgG, in the polyol group. The decrease in all Ig levels during a few days, is attributable to the termination of Ig absorption from the intestines 
and to their distribution to different body fluids and gradual degradation (PORTER 1972, Penhale et al. 1973, Logan et al. 1978 , Sтотт et al. 1979 a, 1979 b). The subsequent significant increase in the levels of all $\mathrm{Ig}$ classes, except for $\mathrm{IgG}_{2}$, can be explained by the activation of the calf's own immune system. Depending on the duration of feeding of colostrum and amount of antibodies in it, the active intestinal synthesis of Ig may commence already within the first week of life (LogAn et al. 1974 b, HusBand and Lascelles 1975, Porter et al. 1977). Also in the saliva, Ig (mainly secretory IgA) is present at one week of age but not at birth (MACH and PAHUd 1971, Butler et al. 1972).

Noteworthy in this context is the behaviour of plasma $\mathrm{IgG}_{1}$ in the polyol group. In comparison to the other groups its level increased considerably less during the first 24 hours, but this was followed by a continuous increase resulting in peak $\mathrm{IgG}_{1}$ level within 35 days. The apparent inhibition of absorption of this particular Ig class, which remains unexplained, was thus compensated by a more vigorous autogenous production. It is interesting to note in this connection that although no statistical differences could be ascertained, haemolytic bacteria associated with diarrhoea were found most frequently in the polyol group. On the other hand, their incidence was lower in the xylitol group which during the colostrum feeding period showed the highest average $\mathrm{IgG}_{1}$ plasma level. It must be noted, however, that the latter group exhibited also the highest average levels of salivary LF and LZM. Also the level of LP was clearly higher in this group than in the glucose group.

These results support the generally accepted opinion of the importance of colostral antibodies to the neonatal calf (Roy
1980). On the other hand, the present results suggest that also the non-specific antimicrobial factors provided both passively from colostrum and actively through an endogenous production may contribute to the protection of the calf during its first weeks of life. It appears that the physiological behaviour of these factors in colostrum and the calf's saliva differ from each other, but are complementary in a logical way, as is the case with immunoglobulins.

Thus, the relatively low concentration of LZM in the first colostrum postpartum seems to be compensated by a high level of this enzyme in the calf's saliva at birth. Conversely, the decreasing levels of colostral LP, upon a short initial increase postpartum, and LF, in particular, seem to be compensated by increasing levels of these proteins in saliva. These changes appear to coincide with the period when the immunological protection provided by antibodies is lowest. At this particular time, the.non-specific factors may, therefore, augment the effect of antibodies to a significant extent, not only by exerting synergistic action with them but also by expanding the range of the calf's antimicrobial defence capacity, especially in the mouth and intestinal tract. It may be assumed that the presence of LF, LZM and LP in the calf's saliva right from the birth is important in controlling the invasion of pathogens, especially between feeding times. Therefore, the concentration of these factors at any time may be of special importance.

The results of this study suggest a potential contributory effect of xylitol intake on the health of the newborn calf but since a statistical confirmation could not be obtained, the validity of this hypothesis remains to be shown in further studies. 


\section{References}

Ahonen, T., Korhonen, H. \& Antila, M. 1978. The characteristics and concentration of lactoferrin in Finnish bovine milk. Meijeritiet. Aikakausk. 36: 68-89.

Baumwart, A.L., Bush, L.J., Mungle, M. \& Corley, L.D. 1977. Effect of potassium isobutyrate on absorption of immunoglobulins from colostrum by calves. J. Daîry Sci. 60: 759-762.

Bush, L.J. \& Staley, T.E. 1980. Absorption of colostral immunoglobulins in newborn calves. J. Dairy Sci. 63: $672-680$.

Butler, J.E. Maxwell, C.F., Pierce, C.S., Hylton, M.B., Asofsky, R. \& Kiddy, C.A. 1972. Studies on the relative synthesis and distribution of $\operatorname{IgA}$ and $\mathrm{IgG}_{1}$ in various tissues and body fluids of the cow. $\mathrm{J}$. Immun. 109: 38-46.

Fahey, J.L. \& McKelvey, E.M. 1965. Quantitative determination of serum immunoglobulins in antibody-agar plates. J. Immun. 94: 84-90.

Gothefors, L. \& MarkLund, S. 1975. Lactoperoxidase activity in human milk and in saliva of newborn infants. Infect. Immun. 11: 1210-1215.

Husband, A.J. \& Lascelles, A.K. 1975. Antibody responses to neonate immunization in calves. Res. Vet. Sci. 18: 201-207.

Jensen, P.T. 1978. Quantitative studies on immunoglobulins, albumin and total protein in serum from young normal calves. Nord. Vet.-Med. 30: 145-154.

Klebanoff, S.J., Clem, W.H. \& Luebke, R. P. 1966. The peroxidase-thiocyanatehydrogen peroxide antimicrobial system. Biochim. Biophys. Acta 117: $63-72$.

Korhonen, H., Meriläinen, V. \& Antila, M. 1978. Ternimaidon koostumus ja merkitys vastasyntyneelle vasikalle. (Significance of colostrum to the health and nutrition of the newborn calf). Suomen Eläinlaaak.lehti 84: 375-391.

-, Rıntamãkı, O. \& Antil.a, M. 1977. A polyol mixture or molasses treated beet pulp in the silage based diet of dairy cows. II. The effect on the lactoperoxidase and thiocyanate content of milk and the udder health. J. Sci. Agric. Soc. Finl. 49: 330-345.

Logan, E.F., McBeath, D.G. \& Lowman, B.G. 1974 a. Quantitative studies on serum immunoglobulin level in suckled calves from birth to five weeks. Vet. Rec. 94: $367-370$.

-, McMurray, C.H., O'Neill, D.G., McParland, P.J. \& McRory, F.J. 1978. Absorption of colostral immunoglobulins by the neonatal calf. Br. Vet. J. 134: 258-262.

-, Stenhouse, A., Ormrod, D.J. \& Penhale, W.J. $1974 \mathrm{~b}$. The role of colostral immunoglobulins in intestinal immunity to enteric colibacillosis in the calf. Res. Vet. Sci. 17: 290-301.

MACH, J.-P. \& PAHUD, J.-J. 1971. Secretory IgA, a major immunoglobulin in most bovine external secretions. J. Immun. 106: 552-563.

McGuire, T.C., Pfeiffer, N.E., Weikel, J.M. \& BARTSCH, R.C. 1976. Failure of colostral immunoglobulin transfer in calves dying from infectious disease. J. Am. Vet. Med. Ass. 169: 713-718.

Merilaìnen, V., Màyrā, A., Korhonen, H., Antila, M. \& Uusi-Rauva, A. 1979. Cells in bovine colostrum and properties of lymphocyte population. Meijeritiet. Aikakausk. 37: 45-58.

Morrison, M. \& Steele, W.F. 1968. Lactoperoxidase, the peroxidase in the salivary gland. In: Biology of the mouth. Ed. Parson, H. American Association for Advancement of Science, Washington D.C., 1968, p. 89-110.

Máinen, K.K., Tenovuo, J. \& Scheinin, A. 1975. Turku sugar studies. XII. The effect of the diet on oral peroxidases, redox potential and the concentration of ionizable fluorine, iodine and thiocyanate. Acta Odont. Scand. 33, Suppl. 70: 247-263.

NAYlor, J.M. \& KRonfeld, D.S. 1977. Refractometry as a measure of the immunoglobulin status of the newborn dairy calf: Comparison with the zinc sulfate turbidity test and single radial immunodiffusion. Am. J. Vet. Res. 38: 1331-1334.

Parry, R.M. Jr., Chandan, R.C. \& Shahani, K.M. 1965. A rapid and sensitive assay of muramidase. Proc. Soc. Exp. Biol. Med. 119: 384-386.

Penhale, W.J., Logan, E.F., Selman, I.E., Fisher, E.W. \& McEwan, A.D. 1973. Observations on the absorption of colostral immunoglobulins by the neonatal calf and their significance in colibacillosis. Ann. Rech. Vet. 4: 223.

Porter, P. 1972. Immunoglobulins in bovine mammary secretions. Quantitative changes in early lactation and absorption by the neonatal calf. Immunology 23: $225-238$.

-, Parry, S.H. \& Allen, W.D. 1977. Significance of immune mechanisms in relation to enteric infections of the gastrointestinal tract in animals. In: Immunology of the gut. Ciba Found. Symp. 46 (new series), Elsevier Exerpta Medica, North-Holland, Amsterdam, p. $55-67$.

ReIter, B. 1978 a. Review of the progress of dairy science: antimicrobial systems in milk. J. Dairy Res. 45: $131-147$.

-1978 b. Review of nonspecific antimicrobial factors in colostrum. Ann. Rech. Vet. 9: 205-224.

-, Marshall, V.M., Bjorck, L. \& Rosen, C.G. 1976. The non-specific bactericidal activity of the lactoperoxidase-thiocyanate-hydrogen peroxide system of milk against E.coli and some Gram-negative pathogens. Infect. Immun. 13: 800-807.

-, Marshall, V.M. \& Phillips, S.M. 1980. The antibiotic activity of the lactoperoxidase-thiocyanatehydrogen peroxide system in the calf abomasum. Res. Vet. Sci. 28: 116-122. 
-, Pickering, A. \& Oram, J.D. 1964. An inhibitory system lactoperoxidase-thiocyanate-peroxide in raw milk. In: Microbial Inhibitors in Food. Ed. N. Molin, p. 297-305, Almqvist \& Wiksell, Stockholm.

Roy, J.H.B. 1980. Factors affecting susceptibility of calves to disease. J. Dairy Sci. 63: 650-664.

Stotr, G.H. \& Menefee, B.E. 1978. Selective absorption of immunoglobulin IgM in the newborn calf. J. Dairy Sci. 61: 461-466.

-, Marx, D.B., Menefee, B.E. \& Nightengale, G.T. 1979 a. Colostral immunoglobulin transfer in calves.
I. Period of absorption. J. Dairy Sci. 62: 16321638.

-, Marx, D.B., Menefee, B.E. \& Nightengale, G.T. 1979 b. Colostral immunoglobulin transfer in calves. II. The rate of absorption. J. Dairy Sci. 62: 17661773.

TuORI, M. 1984. Xylitol, polyol molasses and glucose in the diet of newborn calves. I. Effect on growth and some blood values. J. Agr. Sci. Finl. 56: 299-308.

Ms received December 9, 1984

\section{SELOSTUS}

\section{Ksylitoli, polyolimelassi ja glukoosi vastasyntyneiden vasikoiden dieetissä} II. Antimikrobiset tekijät veressä ja syljessä, sonnan bakteerisisältö ja eläinten terveys

\author{
Hannu Korhonen' ${ }^{1}$ Eija Alasaari ja \\ Matti Antila \\ Helsingin yliopisto, maitotaloustieteen laitos, \\ 00710 Helsinki 71
}

\section{Mikko Tuori ja Esko Poutiainen \\ Helsingin yliopisto, kotieläintieteen laitos, 00710 Helsinki 71}

Kokeessa tutkittiin eräiden antimikrobisten tekijöiden pitoisuutta vastasyntyneiden vasikoiden veressä ja syljessä. Lisăksi tutkittiin ksylitoli- ja polyolimelassilisăn vaikutusta näihin tekijöihin vertailuryhmän saadessa vastaavan määrän glukoosia (n. $1 \mathrm{~g}$ /elopainokilo).

Kaikkiaan 18 vasikalta otettiin veri- ja sylkinäytteitå syntymăn jălkeen ennen ensimmäistă ruokintaa ja sitten 1,2 , ja 4 päivän sekä 1,3 ja 5 viikon iässä. Seuraavat tekijăt tutkittiin kvantitatiivisesti: laktoferriini (LF), laktoperoksidi (LP), lysotsyymi (LZM) sekă immunoglobuliinit $\operatorname{IgG}_{1}, \operatorname{IgG}_{2}, \operatorname{Ig} M$ ja $\lg A$ (vain plasmasta).

Kerran viikossa otetuista sontanäytteistă määritettiin

\footnotetext{
' Nykyinen osoite:

Ministry of Livestock Development,

P.O. Box 68228, Hill Plaza, Nairobi, Kenia.
}

bakteerien kokonaismäărä sekä anaerobisten hemolyyttien, koliformien, laktobasillien ja klostridien määrät. Ainoa tilastollisesti merkitsevă ero bakteerimaaărissă oli ksylitoliryhmän korkein klostridipitoisuus $(\mathrm{P}<0.05)$. Hemolyyttisten bakteerien runsas esiintyminen oli yhteydessă vasikoiden ripuliin.

Tulokset osoittavat, ettă immunoglobuliinien lisăksi myös ternimaidossa esiintyvät $L F, L Z M$ ja LP vaikuttavat huomattavasti vasikan vastustuskyvyn muodostumiseen patogeenisia mikrobeja vastaan ensimmäisină elinviikkoina. 